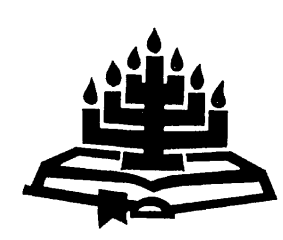

\title{
'n Prakties-teologiese perspektief op die handeling van kerklike besluitneming: praktykteorie
}

\author{
F.W de Wet \& F.P. Kruger \\ Skool vir Kerkwetenskappe \\ Potchefstroomkampus \\ Noordwes-Universiteit \\ POTCHEFSTROOM \\ E-pos: fritz.dewet@nwu.ac.za \\ ferdikruger@mweb.co.za
}

\begin{abstract}
A practical-theoretical perspective on the act of making ecclesiastical resolutions: theory for praxis
\end{abstract}

In a preceding article the researchers unfolded the problematic praxis concerning ecclesiastical resolution-making by referring to insufficient accountability with respect to the way in which human prejudice and desire (anthroponomic elements) can (unconsciously) dominate the mind in calling upon Scripture and guidance of the Spirit (theonomic elements). In this followup article we try to propose a strategy for change by developing a praxis theory for ways in which the complexity of the relationship between divine and human elements in the resolutionmaking process (and especially with respect to the hermeneutical complexity involved in calling upon Scripture) can be visualised. Our purpose with this praxis theoretical exercise will then be to provide people involved in the resolution-making process with beacons with a view to discerning what may on the surface look like a theonomically determined resolution, but what might in fact be resolution that will eventually radicalise in polarisation due to dominating antroponomic elements. The researchers assess the heart of a strategy for reversing the disintegrating factors in the attitudes and viewpoints of resolution makers into integration to lie in the reconciling power of the gospel of grace in Jesus Christ. Where people willingly place themselves under die guidance of the Spirit of Christ the process of resolution-making will be a balanced process without absolutising or relativising Scripture. 


\section{Opsomming}

\section{'n Prakties-teologiese perspektief op die handeling van kerklike besluitneming: praktykteorie}

In 'n voorafgaande artikel het die navorsers die problematiese praksis rakende kerklike besluitneming ontvou deur te verwys na 'n gebrekkige verrekening van die manier waarop menslike voorkeure en denkraamwerke (antroponome elemente) besluitnemers, sonder dat hulle altyd daarvan bewus is, kan oorheers in hulle beroep op die leiding deur die Woord en Gees (teonome elemente). In hierdie opvolgartikel word gepoog om veranderingstrategies op praktykteoretiese vlak te besin oor maniere waarop die kompleksiteit van die verhouding tussen Goddelike en menslike elemente (asook die hermeneutiese kompleksiteit wat in Skrifberoep ter sprake kom) in die besluitnemingsproses gevisualiseer kan word. Die doel van die praktykteoretiese merkers sou wees om aan besluitnemers 'n klankbord te gee om te kan onderskei hoe 'n besluit, wat op die oog af teonoom bepaald lyk, tog deur oorheersende antroponome faktore kan radikaliseer in polarisasie. Na die oordeel van die navorsers is die hart van 'n veranderingstrategie waarin gepoog word om disintegrerende gesindhede en standpunte te oorkom, geleë in die versoenende krag van die evangelie van genade in Christus Jesus. Waar mense hulle deur die Gees van Christus laat lei, word besluitneming gewillig onder leiding van die Gees geplaas sonder dat die Skrif misbruik word om die eie standpunt te verabsoluteer of die Skrif te relativeer.

\section{Inleiding}

Mellody en Theron (2006:113; vgl. Heitink, 1993:277-279) het aangetoon dat kerklike besluitneming nie 'n eenvoudige saak in 'n postmoderne era is nie. Die oorsaak hiervan lê volgens bogenoemde outeurs enersyds opgesluit in die spanning tussen die dinamika wat in die kerk plaasvind en die dinamika wat in die wêreld heers. Andersyds is daar ook dikwels spanning ten opsigte van die mate waarin besluite by meerdere vergaderings die behoeftes van plaaslike gemeentes weerspieël. Bisshoff et al. (2001:33-56) maan op hulle beurt dat die rol van die postmoderne denke in die manier waarop deelnemers aan die besluitnemingsproses (dikwels mense wat in kerklike ampte staan) bejeën word, nie hierin onderskat moet word nie. Vroeër is die rol van die ampte gesien as die "guardians of tradition". Lissack en Roos (2000:5) het op hulle beurt die rol van die ampte in 'n postmoderne era beskryf as een waarin 'n konteks geskep moet word waarin lidmate samehang (coherence) kan vind. In 'n postmoderne samelewing word die rol en optrede van die ampte 
toenemend met skeptisisme bejeën (Stoffels, 1999:83). Op voetspoor hiervan vra Hefer (2009:16) of meerdere vergaderings die Here verkeerd kan hoor. Hy vra die vraag teen die agtergrond daarvan dat kerklike vergaderings, en dus ook besluite, feilbaar is. Daarom waarsku bogenoemde outeur daarteen dat tradisies en onskriftuurlike ideologieë kan meebring dat vergaderings die Here verkeerd hoor. Bisshoff et al. (2001:55) sluit hierby aan deur op die sosiopolitieke bedeling te wys waarin Suid-Afrika tans lewe en wat bepalend is vir lidmate se kritiese vrae oor leierskap. De Wet (2007:7-8) beskryf op sy beurt die uitwerking van sodanige stand van sake deur aan te toon dat meningsverskille tussen gelowiges dikwels daartoe aanleiding gee dat aanhangers van 'n bepaalde standpunt andersdenkendes daarvan beskuldig dat hulle met 'n ander Skrifbeskouing werk. Na die oordeel van die outeurs van hierdie artikel het professor Callie Coetzee, met sy kenmerkende skerp onderskeidingsvermoë en insig, 'n besondere bydrae gelewer in die wetenskaplike besinning oor en die praktyk van eenheid in die kerklike lewe en besluitnemingsprosesse (Coetzee, 2006:16). Ons wil graag hierdie artikel, waarin wetenskaplik geworstel word met faktore wat diensbaar kan wees tot eenheid van die kerk in die spanningsveld van besluitneming, aan hom opdra in dankbaarheid vir die mooi gawes wat aan hierdie kollega toevertrou is.

In die outeurs se voorafgaande artikel (De Wet \& Kruger, 2010:1-25) rakende die problematiek rondom kerklike besluitneming, is aangedui hoe daar vanuit 'n praktiesteologiese invalshoek met die volgende navorsingsvraag gewerk word: In hoe 'n mate het die problematiese praksis rondom kerklike besluitneming te make met 'n oorvereenvoudigde persepsie rakende die pneumatologiese dinamika wat ter sprake kom in besluite waarvan gesê word: "die Heilige Gees en ons het besluit"? In die aanvanklike verkenning van hierdie navorsingsvraag is die rol van oorvereenvoudiging in kerklike besluitneming reeds aangedui. Die saak van oorvereenvoudiging is ontvou deur te verwys na 'n gebrekkige verrekening van die manier waarop menslike voorkeure en denkraamwerke (antroponome elemente) besluitnemers - sonder dat hulle altyd daarvan bewus is - kan oorheers in hulle beroep op die leiding deur die Woord en Gees (teonome elemente).

In die voorafgaande artikel, waarin die probleemveld en die normatiewe gesigspunt onderskeidelik as eerste en tweede fase van die navorsingsprojek verken is, het dit duidelik geword dat 'n oorvereenvoudigde begrip ten opsigte van die pneumatologiese dinamika tussen teonome en antroponome faktore tot 'n groot mate 'n bydraende 
faktor kan wees tot die problematiek wat vanuit polariserende besluitneming voortvloei. Daar is ook aangetoon dat die manier waarop hierdie polarisering uitkristalliseer veral te make het met 'n oorvereenvoudiging van die hermeneutiese kompleksiteit wat in die proses van Skrifberoep, met die oog op besluitneming, ter sprake kom. Volgens Vos (1996:250) kan die tendens van problematiese Skrifberoep ook voortspruit uit 'n versethouding van gelowiges teenoor die wêreld. Hierdie versethouding kan uitkristalliseer in 'n ingesteldheid waarin die Woord teen die werklikheid gestel word, in plaas daarvan dat die Woord in die werklikheid gerig word. Sodanige ingesteldheid kan meebring dat die kerk in 'n ghetto verval en dit kan dan maklik gebeur dat kerklike besluitneming ook ontaard in 'n poging om bloot die verlede so lank as moontlik te bewaar. Hierteenoor het Lindner (1994:34) op breedvoerige wyse aangetoon dat die unieke plek van die gelowiges in 'n sekulêre wêreld juis veronderstel is om hulle te posisioneer om hulle roeping in die wêreld uit te leef.

As dokumentering van die derde fase van die navorsingsprojek, word in hierdie opvolgartikel, gepoog om op praktykteoretiese vlak te besin oor ' $n$ besondere handelingspraksis - 'n handelingspraksis waarin die kompleksiteit van die verhouding tussen goddelike en menslike elemente (asook die hermeneutiese kompleksiteit wat in die Skrifberoep ter sprake kom) in die besluitnemingsproses gevisualiseer kan word. Hierdie besinning sou moontlik 'n bydrae kon lewer om aan deelnemers in die besluitnemingsproses 'n diepteblik te gee rakende die faktore wat in hulle en tussen hulle aan die werk is tydens die betrokke proses. Die doel van die praktykteoretiese merkers sou dan wees om aan besluitnemers 'n klankbord te gee om te kan onderskei hoedat ' $n$ besluit wat op die oog af teonoom bepaald lyk, tog deur oorheersende antroponome faktore in 'n sekere rigting gestuur kan word. Uiteindelik sou die praktykteoretiese merkers hopelik kon funksioneer as hulplyne vir en 'n bydraende faktor in die kanalisering van ' $n$ besluitnemingsproses. In hierdie besluitnemingsproses moet die samebindende krag van versoening, orde en die ruimtes van vryheid wat die een Here vir sy kerk oopgemaak het, deur een gemeenskap van heiliges met blymoedige en gewillige harte omhels word; 'n gemeenskap van heiliges waarin ruimte vir mekaar gegee word sonder dat die eenheid wat hulle saambind in gedrang gebring word.

Met die oog op die veranderingstrategiese aard van hierdie finale fase van die ondersoek, word die navorsingsgang soos volg ingedeel: 
- Identifisering van praktykteoretiese instrumente waardeur die spanningsveld wat in kerklike besluitneming ter sprake kom, met die oog op veranderingstrategie gevisualiseer kan word.

- Veranderingstrategiese verkenning van polarisering in die spanningsveld van besluitneming in die lig van die gesonde spanning tussen "ons en die Heilige Gees" wat in Handelinge 15 ter sprake kom.

- Veranderingstrategiese verkenning van die hermeneutiese spanningsveld wat in die Skrifberoep as normatiewe rigtingwyser vir besluitneming funksioneer.

\section{Identifisering van praktykteoretiese instrumente}

Deur hierdie praktykteoretiese instrumente behoort die spanningsveld wat in kerklike besluitneming ter sprake kom, met die oog op veranderingstrategie, gevisualiseer te kan word. Ten einde 'n diepteblik te verkry in die prosesse wat tydens besluitneming aan die werk is, is dit nodig om 'n beeld te vorm van die besluitnemingsveld en die kragte wat daarin aan die werk is. Dit sou nodig wees om in die geloof te visualiseer dat dit hier gaan om ' $n$ handelingsveld waarin daar ' $n$ bepaalde spanning bestaan tussen die goddelike wil en die mate waarin die mens teen hierdie wil weerstand bied of gewillig daaraan gehoorsaam is. Dit gaan in hierdie spanningsveld oor die verskil tussen hoe lieflik dit is waar die goddelike wil in die volle stralende heerlikheid daarvan in die menslike gees weerspieël word, of aan die ander kant, hoe bedroewend dit is waar die wil van God verduister of ingeperk word. Pieterse (1985:20-21) het oor die gewilligheid om God te gehoorsaam, opgemerk dat indien die Bybel bloot as 'n studie-objek hanteer word, die Bybel in werklikheid tot swye gebring word. Wanneer daar gelowig en gehoorsaam hierna geluister word, spreek die Bybelteks as die Woord van God. Die doel van hierdie diepteblik wat die artikel wil bied, is om die waarnemer bewus te maak van oorvereenvoudigde en eendimensionele elemente in die manier waarop hy/sy die veld van besluitneming moontlik mag beskou. Vanhoozer (2005:91) het in hierdie opsig verwys na die verskuiwende fokus in die moderne tyd vanaf die bedoeling van die skrywer na die konteksbepaaldheid van die hoorder in 'n soeke na wat vir hom/haar relevant is. Hiermee het hy die saak aangeraak van die belangrikheid daarvan om die Woord van God en die werklikheid van die 21e eeu in 'n kragtige verhouding tot mekaar te bring. Ten einde 'n praktykteologiese instrument te identifiseer waarvolgens ' $n$ akkurate visualisering kan plaasvind van die ruimtes wat in die besluitnemingsveld plaasvind, kan verwys word na Zijlstra 
(1989:24). Hy sluit aan by die insigte van die filosofiese antropologie en dieptepsigologie wat daarin bestaan dat die menslike eksistensie in die grondstrukture daarvan 'n polêre karakter vertoon. Die polêre spanning sorg vir 'n dinamiek en maak groei- en bewuswordingsprosesse moontlik. 'n Versteuring in die ewewig van die polêre spanning kan tot ambivalensies, angs, verwarring en verstarring aanleiding gee (vgl. Van Pelt, 1999:23).

Hierdie polêre karakter sou nie alleen in die horisontale dimensie (intrapersoonlike en interpersoonlike dimensie) van die menslike bestaan gevisualiseer kon word nie, maar sou ook in die vertikale dimensie (geloofsverhouding met God) weerspieël word. Toegepas op die spanningsveld van kerklike besluitneming: Daar sou 'n kenmerkende bipolêre dinamika wees waardeur die interaksie in die kommunikatiewe en standpuntvormende aktiwiteite gekenmerk word; 'n polêre spanning nie alleen ten opsigte van die balans tussen vryheid en verantwoordelikheid in die intrapersoonlike oorweging en ten opsigte van behoudendheid of progressiwiteit in intermenslike verhoudings nie, maar ook ten opsigte van die balans tussen teonomiteit en ongeforseerde menslike toeëiening in die vertikale dimensie van die spanningsveld. Sonder die gesonde spanning van hierdie handelingsveld sou die mens se perspektief waarmee hy na die lewe kyk in eensydighede en radikalisering verval, sou menslike verhoudings disintegreer, en sou die verhouding met God tot 'n skynheilige verhouding vervals waarin dit wat vir God aanneemlik is, onregmatig betrek word by 'n standpunt wat in werklikheid eie voorkeur weergee.

Die balans tussen die polêre faktore in die handelingsveld van besluitneming kan op 'n eenvoudige wyse soos volg gevisualiseer word:

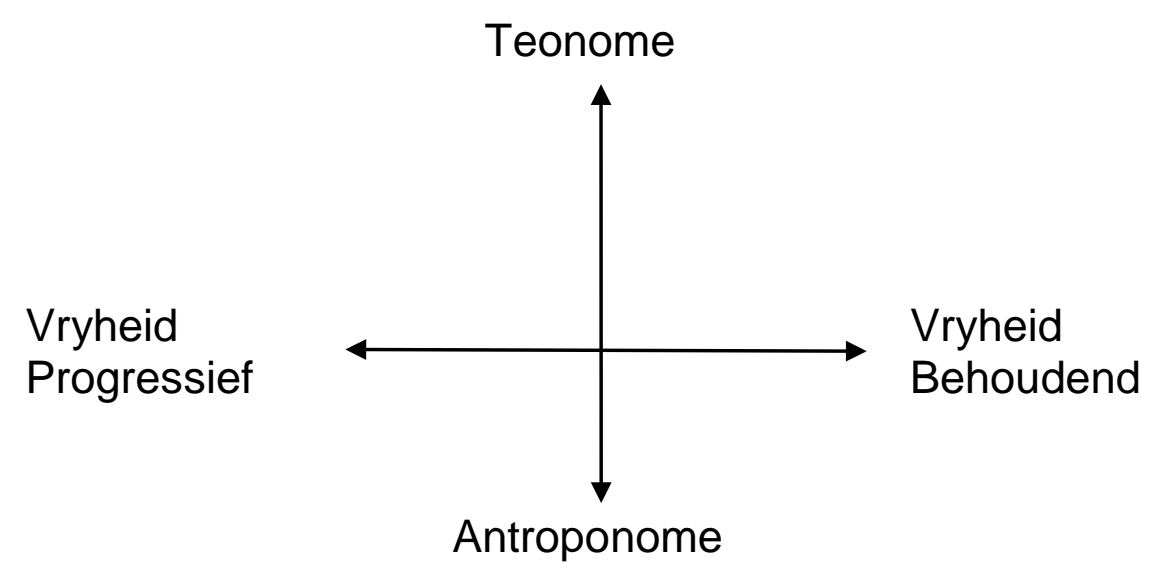


Die bipolêre verhouding kan in polarisasie ontaard wanneer standpuntvorming in afstotende teëpole radikaliseer. Integrasie maak plek vir disintegrasie. Hier kan aangesluit word by die sisteemdenke van Louw. Hy maak gebruik van 'n model met 'n horisontale as en 'n vertikale as om die dimensies in die ontmoetingsruimte oop te maak. Die hele bedoeling van die gebruikmaking van 'n skema is volgens Louw (2005:28 e.v.) hermeneuties van aard, naamlik om te verstaan hoe mense hulleself binne verhoudingsnetwerke posisioneer. Dit wil tendense binne die ontmoetingsruimte tussen mense aandui. Dit wil ook houdings en pole beskryf wat binne verhoudingsnetwerke aanwesig is. Dit wil bepaalde tendense en polêre spanninge beskryf en artikuleer. Heyns kwalifiseer die horisontale as as 'n ervaringsas en die vertikale as as die normatiewe gesags- en etiese as. Op die horisontale as kan byvoorbeeld afstand en nabyheid bipolêr aan mekaar verbind word. Nabyheid beskryf die pool van samesyn en ontmoeting. Afstand beskryf die pool van uniekheid en eiesoortigheid. Die verhoudingsnetwerk kan siek raak wanneer gevaarsones betree word en disfunksionele houdings intree wat vir die bepaalde bipolêre verwantskap ontoepaslik is. Die pool van afstand word geradikaliseer in weerstand/verwerping. Die pool van nabyheid kan in versmoring ontaard. Op die vertikale as kan leiding 'n bipolêre verwantskap met ondersteuning vorm. Leierskap dui op 'n direktiewe, rigtinggewende en singewende komponent in die verhoudingsnetwerk, terwyl wedersydse ondersteuning verteenwoordigend is van die pool van toewyding. Die gevaarsone word betree en verhouingspatologie ontwikkel wanneer leierskap in outoritêre dominering en ondersteuning in manipulasie ontaard.

Larsen (1989:138 e.v.) toon aan dat manipulasie eie is aan 'n situasie van polarisasie. 'n Manipuleerder wil ten diepste beheer van die situasie oorneem kragtens 'n verengde denkpatroon waaraan hy ook ander gelowiges wil onderwerp. Herholdt (1995:126-129) sluit aan by die gedagte oor die mate waarin manipulasie versteurend in verhoudingsnetwerke kan werk en spreek sy besorgdheid uit oor die geneigdheid van sekere kerklike leiers wat tekste in die Bybel aanhaal om hulle sienings te legitimeer, maar sodoende die gebrek aan liefde kamoefleer. Die gevaar hieraan verbonde is dat die Bybel sodoende misbruik word om goddelike sanksionering op te eis vir die eie groep se standpunt en gewetens te bind. Dit kom op niks anders neer nie as manipulasie (Herholdt, 1995:126). Joubert (2003:89) merk hieroor op dat die meeste dwalings en onreg dikwels onder die gewaad van die Woord voortspruit. Gelowiges moet in kerklike besluitneming egter getuies bly van wat die Skrif leer. Dit bring mee dat gelowiges se getuienis voortdurend aan die Woord self getoets 
moet word. Deist (1986:100-101) beklemtoon voorts die gevaar dat kerklike vergaderings in hulle Skrifberoep/Skrifgebruik die Bybel as 'n boek van aanhalings kan gebruik om sodoende te manipuleer. 'n Kerklike vergadering wat daarop aanspraak maak dat die Heilige Gees hulle lei in besluitneming, moet daarom erns maak daarmee om nie te manipuleer nie en om nie die Bybel buite konteks te gebruik nie.

Die manier waarop die normale teëpole in die bipolêre verhouding in disfunksionele houdings geradikaliseer kan word, kan soos volg gevisualiseer word:

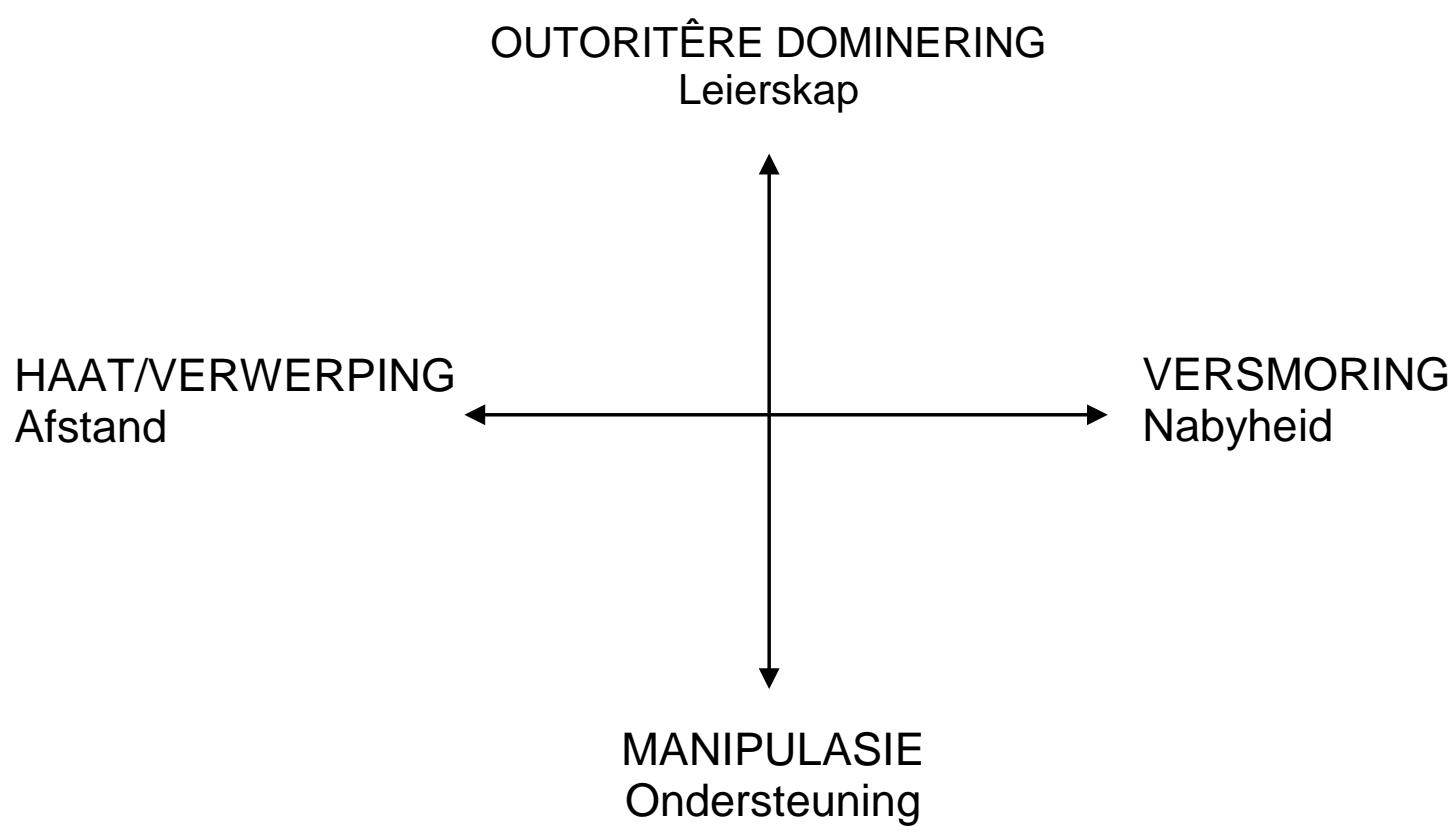

\section{Veranderingstrategiese verkenning van polarisering}

Hierdie verkenning van polarisering in die spanningsveld van besluitneming vind plaas in die lig van die gesonde spanning tussen "ons en die Heilige Gees" wat in Handelinge 15 ter sprake kom. Die besluitneming in Handelinge 15 vind plaas in die spanningsveld van 'n kerklike praksis waarin daar kragte aan die werk is wat dreig om lidmate van die kerk van mekaar te vervreem. In die een standpunt word die suiwerheid en heiligheid van die kerklike lewe beklemtoon. In hierdie standpunt word die verantwoordelikheid van lidmate van die kerk om die patrone van heiligheid en suiwerheid wat God oorspronklik aan sy verbondsgemeenskap toevertrou het (soos dit in die wet van Moses geopenbaar is), beklemtoon. Aan die ander kant van die spektrum staan die belangrikheid daarvan om die vryheid (na die volle mate daarvan wat God vir mense in Christus wil gee, 
soos Hy dit in die Woord duidelik maak en die harte van mense deur die werking van Heilige Gees reinig) te beskerm van mense uit die heidene wat hulle tot die Christelike geloof bekeer het. Hierdie mense moet nie opnuut onder 'n slawejuk ingedwing word nie. In 'n gesonde spanningsveld sou hierdie twee pole funksioneer as twee ankers wat albei standpunte uitbalanseer en in staat stel om nie in eensydigheid na die een of die ander kant te radikaliseer (polariseer) nie.

'n Ander dimensie wat in die spanningsveld ter sprake kom, is die verhouding tussen teonome (die Heilige Gees, as die Een deur wie die kerk in die volle waarheid van die wil van God gelei word) en antroponome (en ons, die kerklike gemeenskap as 'n gemeenskap wat deur Christus vrygemaak is om werklik vry te wees en God gewillig met gereinigde harte te kan dien). Die wil van God en sy eer speel 'n primêre rol in die gerigtheid waarmee tot besluitneming gekom word. Alleen God, die Kenner van menseharte, weet wat vir sy kerk goed is. Slegs onder die onbevange leiding deur die Heilige Gees kan die volle waarheid van God, soos dit in sy Woord geopenbaar word, aan die kerk gebring word tot die volle doel wat God daarvoor beskik het. Aan die ander kant word mense nie op 'n willose en meganiese manier en met die verlies van hulle menswees gelei en met verlies van gewilligheid ten opsigte van hulle kindskap van God gelei in besluitneming deur die Gees nie. In 'n gesonde inkleding van die spanningsveld word dít wat tot eer van God dien en 'n weerspieëling is van die volle ruimte van geïntegreerde lewe vir sy kerk (ruimte waarin die lewe kan floreer), gewillig in die geloof omhels. In Suid-Afrika het Cilliers (2000:90) heelwat navorsing gedoen oor die verskynsel van wettisisme soos dit veral in prediking na vore kan kom. Hy het onder andere die gevaar uitgestippel wat ook vir kerklike vergaderings geld, naamlik dat gelowiges die visie op God self kan verloor. Hulle kan later so onoortuigend oor sy handelinge in die verlede en toekoms praat dat hulle in die hede in allerlei menslike aktiwiteite wegvlug. Cilliers (1996:12-14) wys in ander navorsing op die gevare wanneer wet en evangelie nie in die regte verhouding tot mekaar staan nie en die mens dus 'n té prominente rol vertolk. Hy lig veral twee gevolge uit, naamlik dat die wettiese optrede die Bybel laat verstom en dat die inhoud van die Woord aangetas word.

Uit die gedagtegang van Handelinge 15 blyk dat in die besluitneming gesonde spanning in die bipolêre verhoudingsdinamika gehandhaaf moet word - wat op sowel die horisontale as die vertikale vlak ter sprake kom. Daar is 'n balans gevind tussen vryheid en 
verantwoordelikheid. Daar is ook by 'n punt gekom waar alle persepsies vermy is wat tot dwangmatige manipulasie of willekeurigheid in die verhouding tussen die Goddelike Gees en die menslike harte aanleiding kon gee. Dit is opmerklik dat die besluit in geen rigting in ekstremiteit opgaan nie. Dit is ook opmerklik dat die besluit rus in die kerke gebring het. Almal was baie bly oor die bemoedigende boodskap wat in die skrywe vervat is waarin die besluit gekommunikeer is (Hand. 15:31).

Indien hierdie gesonde spanning waarvan in Handelinge 15 sprake is, nie gehandhaaf word nie, kan die besluitnemingsveld skeefgetrek word of deur disintegrerende kragte oorgeneem word. Dit is veranderingstragegies belangrik dat die waarnemer bewus raak van die kenmerkende maniere waarop hierdie besluitnemingsveld kan skeeftrek. Daar moet dus op 'n perspektief-verruimende en selfverloënende manier teruggekeer word tot die bipolêre balans wat noodsaaklik is in verantwoordelike besluitneming. Wanneer polarisasie plaasvind, word die balans van dit wat nodig is om die lewe van die kerk te laat floreer, uitmekaar geskeur. In die spanningsveld wat in besluitneming ter sprake kom, kan onder andere die volgende afstotende/polariserende kragte werksaam wees:

- Die spanningsveld kan radikaliseer tussen die mate waarin vryheid misbruik word, deur besluitneming byvoorbeeld te laat aanpas by 'n sekulêre wêreld waarin die patroon van heilige orde van God vir die menslike lewe versteur word. Verantwoordelikheid kan ook misbruik word deur besluitneming byvoorbeeld deur wettiese rigiditeit te laat inperk in die verskansing van die eie gevestigde posisie.

- In die spanningsveld kan die Gees van God weerstaan of bedroef word. Dit gebeur deurdat mense hulle eie voorkeure (eie gemanipuleerde, eensydige interpretasie van die waarheid), sonder dat hulle dit besef, inklee asof dit in ooreenstemming met die Woord (en daarom ook met die Gees) is. Hule hou dit voor as die enigste waarheid; of aan die ander kant, sonder dat hulle dit besef, beklemtoon hulle die menslike element sodanig dat die gesag van die Skrif uitgerafel word en relatief gemaak word ten opsigte van die veranderende menslike konteks.

Die radikalisering van standpunte kan volgens De Wet (2007:9-10) ' $n$ verskeurende invloed op die kerk uitoefen, byvoorbeeld deur verdagmakery asook deur gebrekkige gebalanseerde denke te laat posvat. Gebalanseerde denke bring mee dat behoudende denke as anker in gesprekke dien, terwyl vooruitgangdenke die kerk van 
isolasie bewaar (Johnston, 2001:10). Dit moet verder in berekening gebring word dat indien persone oor kerklike sake verskil, hulle nie net oor die substansie van die saak verskil nie, maar ook op 'n interpersoonlike en intrapersoonlike vlak (Gunnink, 1989:79-81). Dit bring mee dat sekere gelowiges antagonisties teenoor die nuwe sake staan, terwyl ander weer ongeduldig raak oor gebrekkige vooruitgang. Al hierdie aspekte beklemtoon die verantwoordelikheid van kerklike vergaderings om verantwoordelik met die Woord om te gaan, sodat Skrifgebruik nie in rigiditeit verval nie. Dit moet sodanig plaasvind dat die krag van die Woord deurbreek (De Wet, 2007:8).

Uit bogenoemde bespreking kan die afleiding gemaak word dat die gevaar bestaan dat Woord en Gees in kerklike besluitneming van mekaar geskei kan word. Wanneer die Gees van die Woord geskei word, ontaard besluitneming in anargisme. Indien die Woord van die Gees geskei word, word mense base (despote) onder die skuiling van die Woord, maar los van die vryheid van die Gees. Die verskynsel van verskeurdheid word dan 'n akute realiteit, omdat gelowiges se gewetens nie meer deur die Woord gebind word nie, maar deur die mees oortuigende standpunt van die betrokke vergadering. Die basis van besluitneming by die vergadering van Handelinge 15 was nie die sentimente van die meerderheid, of die gesag van die tradisie nie, maar wel die boodskap aangaande Jesus Christus (vgl. Wiarda, 2003:245). Groenewald (1986:466) benadruk dit dat indien die besluit in Jerusalem nie die boodskap van die evangelie bevestig het nie, dit op 'n skeuring in die jong kerk van Antiochië sou uitgeloop het. Kerklike besluitneming dra daarom altyd die kiem in homself dat dit gelowiges uitmekaar kan dryf, of positief gestel, nader aan die kernsaak, naamlik God se Woord, kan bring.

Die manier waarop die normale teëpole in die bipolêre verhouding, soos dit uit die besluitnemingsproses in Handelinge 15 blyk, in disfunksionele houdings geradikaliseer kan word, kan soos volg gevisualiseer word: 
RIGIDITEIT

Verantwoordelikheid

OUTORITÊRE MAGSMISBRUIK

"Die Heilige Gees ..."

(persepsie oor teonome)

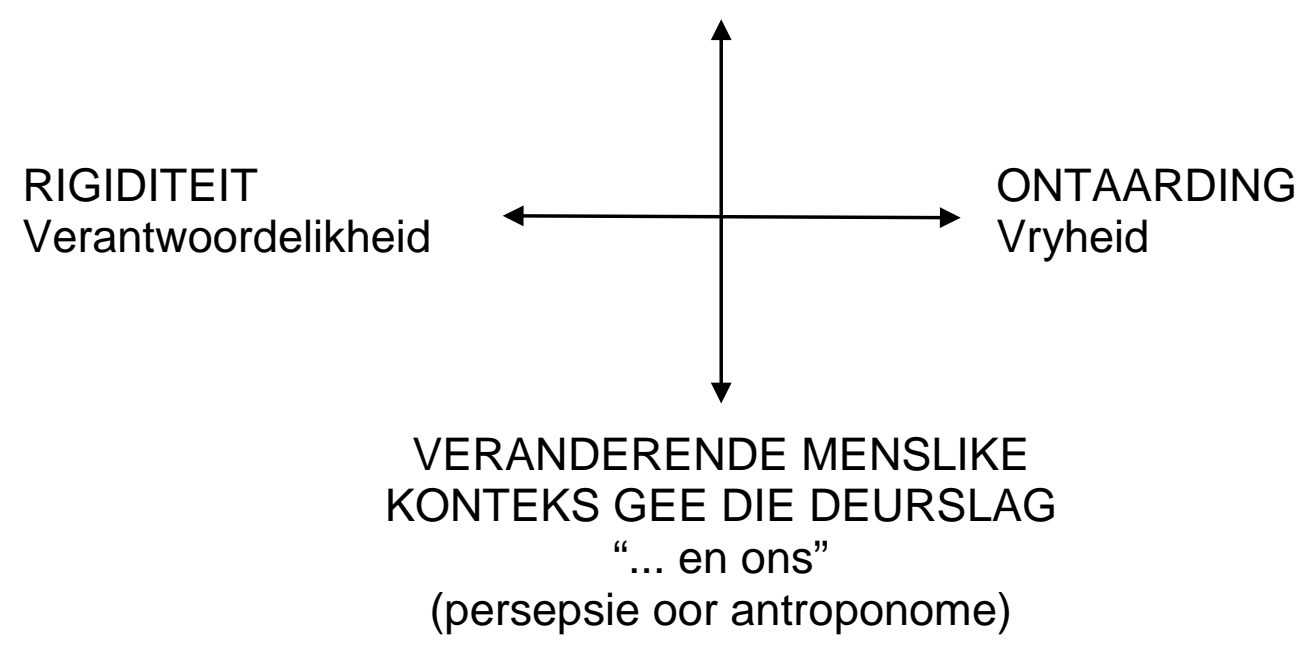

\section{Veranderingstrategiese verkenning van die hermeneutiese spanningsveld}

In die Skrifberoep funksioneer die hermeneutiese spanningsveld as normatiewe rigtingwyser vir besluitneming. In die Gereformeerde konteks gee Skrifgebruik en die hermeneutiek wat daarmee saamgaan die deurslag in die rigting waarin oorwegings rondom 'n kerklike saak voorberei word met die oog op besluitneming. Dit verg egter inspanning en harde werk, wat meebring dat gelowiges deurentyd op die leiding van die Heilige Gees aangewese is, as dié Een wat die Woord oop en verstaanbaar maak (De Klerk \& Janse van Rensburg, 2005:3). Van der Walt (2009:16-26) benader hierdie belangrike saak met die erkenning van die feit van 'n radikale hermeneutiese wending wat in die moderne tyd ingetree het. Dit bring volgens hom mee dat Skrifverklaring noodwendig met 'n wye spektrum faktore rekening moet hou. Silva (1987:7-10) hou hom besig met die vraag of die kerk deur die loop van die eeue moontlik die Bybel verkeerd gelees het. Op sy beurt vestig hy die aandag daarop dat die hermeneutiese wending meebring dat die situasie van die leser, benewens die aksent van die teks, groter aandag kry. Met hierdie inleidende gedagtes as agtergrond, word die hermeneutiese spanningsveld in Skrifberoep van naderby verken.

\subsection{Die noodsaak van gesonde spanning}

Gesonde spanning tussen die Gees-geïnspireerde Skrif en die antroponome elemente in die Skrifverklaarder, wat hom/haar deur die 
Gees laat lei, is noodsaaklik. Die Gees bring die volle rykdom van die verlossing en heiliging wat Jesus Christus, die Here, deur sy kruisdood en opstanding in hierdie wêreld laat deurbreek het. Die kerk word onder leiding van die Gees onder die Hoofskap van hierdie één Here tot 'n lewende eenheid saamgesmee. Die Skrifverklaarder wat hom/haar deur die Gees van Christus laat lei, sal die eie voorkeure afsterf en in 'n lewende eenheid met medegelowiges die leiding wat Christus deur die Woord gee, gewillig volg. Janse van Rensburg en Kruger (2008:80) waarsku teen die gevaar dat mense die Bybel kan misbruik vir die verklaring wat hulle graag wil voorhou. Daarom moet kerklike vergaderings ook voortdurend hulle besluite aan die Skrif kontroleer. Stander (2003:16) voeg by dat niemand dit mag waag om woorde in God se mond te lê nie. Uitleg van die Woord bring altyd implikasies vir ons eie of ons naaste se lewens voort.

Antroponome Skrifuitleg bring nie alleen geestelike skade voort nie, maar kan selfs ook daartoe aanleiding gee dat die fisieke lewe geknou word (Stander, 2003:16-18). Hefer (2009:16) bemerk selfs die gevaar dat kerklike vergaderings in 'n onnadenkende beroep op die beginsel van Handelinge 15:28 (die Heilige Gees en ons het besluit), misbruik kan maak van die teonome primaat wat onderliggend is aan hierdie besluitnemingsverhouding. Die misbruik van die uitspraak kom na vore wanneer gelowiges hulle op die werking van die Heilige Gees beroep, maar hulle eie optrede word nie hierdeur oorheers nie as gevolg van eie voorkeure, vooroordele en willekeur - met ander woorde, as gevolg van antroponoombepaalde elemente. Antroponome Skrifuitleg dwing gelowiges deur middel van besluite sodoende in ' $n$ rigting wat nie deur die Woord aangedui word nie en dit bring gewetensbinding voort. 'n Skrifuitleg waarin aan die antroponome element voorkeur gegee word, maak van die Bybel 'n teks wat by elke situasie moet pas. Die Skrifbewyse wat aangevoer word, het immers die lading van so sê die Here. In kerklike vergaderings gebeur dit dat God sodoende uit verskillende monde praat (Deist, 1982:18). Die vraag word dan aan die adres van kerklike vergaderings gerig, naamlik wie dan reg is en wat die Here werklik oor 'n betrokke saak sê. Antroponome Skrifhantering maak van die Bybel 'n sweep om gelowiges in allerlei kampe in te jaag.

Landau (1981:191) spreek kommer daaroor uit dat God ondergeskik gemaak kan word aan menslike wetmatigheid - die sogenaamde antroponome subordinasie. Hy bestempel dit selfs as die oerskuld van die kerk. De Wet (2005:508) sluit hierby aan en meld dat in die 
hermeneutiese wisselwerking tussen die normatiewe en konkrete werklikheid God en sy Woord tot passiwiteit gedwing kan word. In kerklike besluitneming kan vergaderings die werklikheid sodanig inkleur dat dit neerkom op dit wat die mens in sy vaardigheid kan laat realiseer en verander. Bogenoemde beredenering hou byvoorbeeld implikasies in vir die hantering van kontensieuse sake op meerdere vergaderings soos geslagtelikheid en die besondere dienste. Smit (1995:121) wys op die tendens by kerklike vergaderings dat daar na afloop van vergaderings, ongeag of daar nog verskille mag bestaan, die beslissing gefel word deur die blote telling van stemme. Bogenoemde outeur bemerk in hierdie tendens 'n gebrekkige konflikhantering en 'n gesekulariseerde benadering tot besluitneming. Sodanige wyse van besluitneming bring die eenheid wat die Gees smee in gedrang.

'n Gesonde spanning tussen die Gees-geïnspireerde Woord en die Skrifverklaarder sou meebring dat kerklike vergaderings daarmee rekening moet hou dat die Bybel volgens sy eie aard in besluitneming gebruik moet word (Deist, 1982:48). In kerklike besluitneming moet gelowiges hulle met hulle gewetens voor God verantwoord, juis omdat Skrifberoep en Skrifbewyse gelowiges voor 'n geweldige verantwoordelikheid plaas. Hulle word telkens selfverloënend en integrerend aan die hart van die Skrif gebind, naamlik aan die evangelie van genade in Jesus Christus.

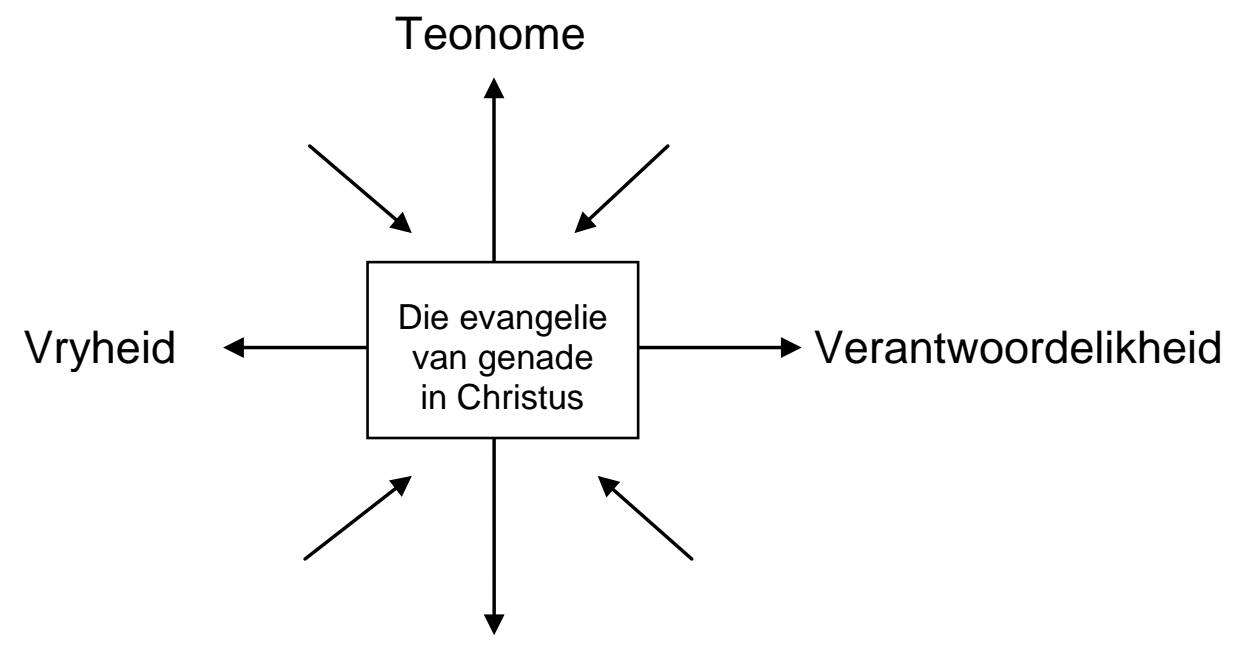

Antroponome

\subsection{Faktore wat aanleiding kan gee tot 'n versteuring van die gesonde spanningsveld}

Daar bestaan 'n gesonde spanningsveld tussen teonome en antroponome aspekte in die hermeneutiese spanningsveld waarin Skrif- 
beroep, met die oog op besluitneming, gebruik word. Stander (2003:13-14) vestig die aandag daarop dat menslike verantwoordelikheid by die lees en verstaan van die Bybel 'n kardinale saak is. Die Heilige Gees maak die kerk nie lui nie en verwag dat gelowiges moeite sal doen om sy Woord reg te hoor en te verstaan. De Klerk en Janse van Rensburg (2005:6) beklemtoon die uitgangspunt dat alle verstaanwerk feilbare mensewerk is. Bogenoemde outeurs illustreer die uitgangspunt aan die hand van twee groepe Skrifverklaarders, naamlik:

- Fundamentaliste: Hierdie verklaarders gee voor dat hulle in die verklaring God bloot nasê en sodoende hulle uitleg gelykstel met die bedoeling van die Gees. Hulle maak maklik daarop aanspraak dat hulle die bedoeling van die Gees weergee.

- Relativiste: Op hulle beurt is hierdie verklaarders van mening dat daar nie iets soos die bedoeling van die Gees is nie. Gelowiges skep self betekenis vanuit die teks wanneer dit gelees word.

Küng (1995:770-773) se navorsing sluit hierby aan deur op twee gesindhede as slaggate in kerklike besluitneming te wys, naamlik ortodoksisme en modernisme.

Die gevare verbonde aan ortodoksisme is dat die stroming van Ortodoksie 'n verstarring betree het waarvolgens alles verstandelik uitgeredeneer word (Van Rooy, 1997:7). Die vryheid van die Reformasie word aan allerlei verstandelike grepe gemuilband. Die modernistiese uitgangspunt het op sy beurt 'n Skrifkritiese en relativistiese siening tot gevolg. Dit beklemtoon die noodsaak van 'n gesonde verhouding tussen die teonome en antroponome pole. In hierdie opsig het Janse van Rensburg en Kruger (2008:84-85) die proses van luister na die bedoeling van die Gees benadruk, waarin gelowiges op voortdurende, nederige en biddende wyse na die regte verklaring van die Bybel moet reik. Dit doen gelowiges in die besef dat die Heilige Gees hulle in die waarheid sal lei. Die gesonde spanningsveld tussen die teonome en antroponome aspekte kan egter versteur word wanneer bogenoemde nie plaasvind nie. Deist (1982: 4) het heelwat vroeër opgemerk dat die odium theologicum (teologiese haat) in moderne tye onverpoost voortgaan. Hy bemerk dit in allerlei kerktwiste en teologies rusies. Almal span Bybeltekste in om hulle standpunte reg te bewys. Volgens Deist (1982:4-5) geskied dit ongelukkig met die gesindheid dat die beroep op die Skrif deur mense bedoel is as 'n uitklophou, terwyl hulle eie vooropgestelde idees agter die Woord verskuil word. Wankelbare opinies word dus agter die onbevraagtekenbare Woord verskuil. Die implikasie hier- 
aan verbonde is dat die Woord sodoende in menslike diens geneem word. Hierdie wyse van Skrifhantering bring mee dat ook gelowiges op nydige wyse op mekaar neersien.

Enkele ander aspekte wat die gesonde spanningsveld kan bedreig, word verder aangestip:

- Verklaarders is nie eerlik oor hulle eie vooronderstellings nie.

- Verklaarders erken nie eerlik dat die bepaalde teologiese tradisie waarin hy/sy staan, Skrifuitleg beïnvloed nie.

- Die verhouding tussen teks en konteks word versteur sodat die vrae wat in die eietydse konteks gevra word, die antwoorde wat die Skrif gee in 'n sekere rigting stuur.

- Die besef dat eietydse probleme meebring dat die Bybel op 'n unieke wyse gelees word teen die agtergrond van hedendaagse problematiek, is gebrekkig.

- Bybeltekste word selektief gebruik om die vooropgesette standpunt van die Skrifverklaarder daarmee te regverdig.

- Aspekte wat op die periferie lê (die sogenaamde middelmatige sake) word oorbeklemtoon sodat die geheelbeeld in die proses verlore gaan.

- Indien kontrolemeganismes nie by die verklaring van die Woord gebruik word nie, word die teonome aspek op die voorgrond geplaas.

- Kerklike vergaderings kan met besluitneming hulle daaraan skuldig maak dat laer getrek word, sodat die eise van veranderende tye nie onnodige spanning voortbring nie.

- Daar is 'n beklemtoning van die verskille tussen die onderskeie standpunte wat deur interpersoonlike spanning en onverdraagsaamheid gedryf word. Hierdeur gaan die perspektief op ooreenkomste verlore. Daar ontstaan sodoende 'n geslotenheid vir die tradisie van ander verklaringsmetodes.

'n Verdere belangrike aspek wat steurend kan inwerk op die spanningsveld tussen die outonome en antroponome pole, is gesindhede. Alle mense beskik oor gesindhede teenoor God, die Woord, die kerk en kerklike besluite. Kruger en Venter (2002:589) toon aan dat die Woord die instelling en vertrekpunt vir die verandering van verkeerde gesindhede is. Vanuit 'n empiriese studie het geblyk dat gelowiges gedeeltelik of volkome daarmee saamstem dat hulle be- 
reid is om hulle gesindhede te verander, indien die Woord van God dit van hulle eis (vgl. Kruger \& Venter, 2003:472). Heyns (1982:1-4) het heelwat vroeër al aangedui dat veranderings in die SuidAfrikaanse konteks gelowiges voor enorme vraagstukke van sowel teoretiese as praktiese aard plaas. Gelowiges word verplig om hulle ten opsigte hiervan te verantwoord. Gelowiges word sodoende ook tot verantwoording ten opsigte van kerklike besluitneming geroep. Kruger en Venter (2003:479-480) bevind verder dat die meerderheid gelowiges negatief voel oor veranderings in die land. Terselfdertyd het die meerderheid respondente te kenne gegee dat hulle verhouding met God vir hulle moed gee vir die toekoms. Dit is 'n gesindheid wat alreeds in die kinderjare (ongeveer op 13 jaar) begin ontwikkel. Volgens (Prins, 2000:86) staan dit bekend as die operasionele fase in kognitiewe ontwikkeling. Oor die verantwoordelikheid van gelowiges toon Kruger (2002:162) aan dat die proses van oorreding gesindhede verander. Hierdie oorreding geskied nie deur middel van dwang en allerlei strategieë nie, maar langs die weg van biddende ondersoek van die Woord deur die inwerking van die Gees. Indien dit nie geskied nie, vind 'n versteuring plaas. Kerklike besluitneming in die lig van die Woord moet derhalwe daartoe bydra dat gelowiges voor die Here geplaas word met hulle gesindhede.

Van Wyk (1995:2-9) verwys op sy beurt na belangrike sosio-politieke kenmerke wat bedreigings, maar in 'n sekere sin ook uitdagings vir gelowiges se besluitneming inhou. Een van die kenmerke waarna hy verwys, is die proses van demokratisering wat wêreldwyd aktueel is. Hiervolgens geld die beginsel dat die meerderheid beslis. Natuurlik is hierdie gedagte nie vreemd aan kerklike vergaderings nie. Van Wyk (1995:2) stel dit egter duidelik dat die waarheid, met ander woorde die Skriftuurlike gehalte, in kerklike besluitneming die deurslag moet gee in plaas van die meerderheid. Waarheid mag nooit aan die meerderheidsdenke ondergeskik gemaak word nie. 'n Verdere sosio-politieke kenmerk waarna Van Wyk (1995:6) verwys, is intellektualisering. Die gevaar hieraan verbonde is dat die mag van die menslike verstand die finale maatstaf kan word in besluitneming. Hiervolgens is ' $n$ bepaalde saak aanvaarbaar of onaanvaarbaar indien dit redelik of onredelik is. Hierteenoor word die maatstaf van Skriftuurlik-verantwoordbaar gestel. Van Rooy (1997:6-10) hou hom besig met die status van afleidings uit die Skrif. Alle menslike afleidings uit die Skrif bly altyd ondergeskik aan die Skrif. Van Rooy waarsku verder daarteen dat kerklike vergaderings nie die Skrif moet laat buikspreek deur afleidings te maak waaroor die Bybel nie antwoorde gee nie. Verkeerde besluite kan by kerklike vergaderings geneem word, soos blyk uit artikels 31 en 46 van die Dordtse 
Kerkorde. Volgens Van Rooy (1997:8) is dit dus belangrik om te begryp dat alle besluite van kerklike vergaderings toetsbaar bly aan die Skrif. Van Rooy (1997:9) beskou die volgende sake as faktore wat belemmerend op die gesonde spanning tussen die teonome en antroponome faktore kan inwerk:

- Eie standpunte kan maklik verabsoluteer word. Hierteenoor moet begryp word dat slegs God se Woord onfeilbaar is en nie mense s'n nie.

- Die interpretasie van die Skrif, die toepassing hiervan asook die hantering van verskille moet op nederige wyse geskied met begrip van die eie beperkings.

- Die aanvaarding van medegelowiges se goeie trou is van kardinale belang. 'n Gebrek hieraan bring 'n verkeerde gesindheid van onwilligheid om deurtastend te luister, na vore.

Smit (2008:405) beskryf die versteuring van die gesonde verhouding tussen die teonome en antroponome faktore as die sondige neiging van mense om in 'n mindere of meerdere mate oor die Gees te wil beskik. Hierdie geneigdheid bring talle kortsluitings voort soos onder andere emosiegedrewe willekeurigheid onder die waan van die leiding van die Heilige Gees (Smit, 2008:405). Hierdeur word 'n beroep gedoen op 'n waarheid deur die bekendmaking van die Gees, sonder om dit aan die Woord te toets. In hierdie proses word 'n antroponome (mensgedrewe) kerkregering in die hand gewerk (Smit, 2008:406).

\subsection{Veranderingstrategiese visualisering van polarisering}

Polarisering vind plaas tussen teonome en atroponome aspekte in die hermeneutiese spanningsveld van Skrifverklaring met die oog op kerklike besluitneming. 'n Radikalisering ten opsigte van die teonoom-verantwoordelikheidskwadrant kan ontstaan wanneer met die (oorvereenvoudigde) persepsie by Skrifverklaarders gewerk word dat 'n letterlike verklaring van die teks (sonder om konteks enigsins in ag te neem en sonder om die menslike vooronderstellings wat in die verklaarder teenwoordig mag wees) gelyk is aan die ontwyfelbare (enigste) goddelike waarheid.

Aan die ander kant van die geradikaliseerde spektrum, kan 'n oorvereenvoudigde persepsie ten opsigte van die vryheid van die Skrifverklaarder en die kompleksiteit van die werklikheid waarin die Skrif verklaar moet word 'n polarisasie laat ontstaan in die antroponome-vryheidskwadrant. Die Heilige Gees kan in albei gevalle ten 
onregte by 'n sondige besluit betrek word om die geloofwaardigheid en gesag daarvan te probeer versterk.

Die konfigurasie van die impak van rigiede teenoor vrysinnige Skrifgebruik, asook die uiteenlopende standpuntinname wat daaruit op die besluitnemingsproses voortvloei, kan visueel soos volg voorgestel word:

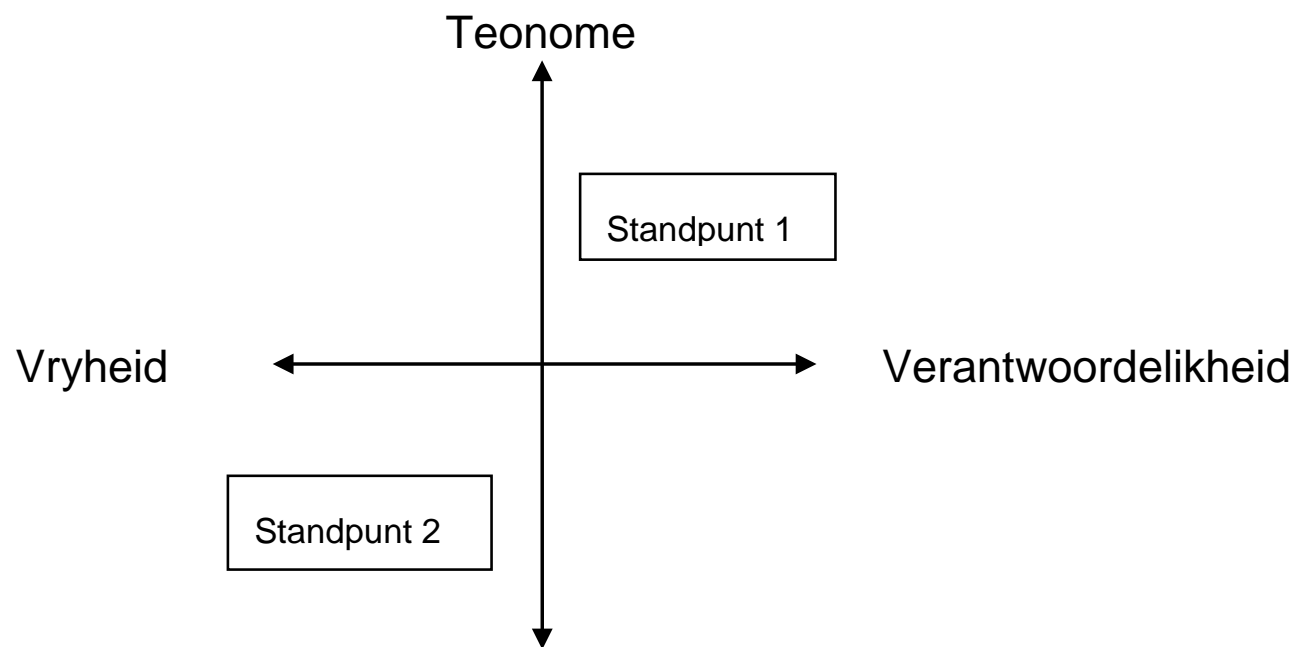

Antroponome

Die implikasie van hierdie polarisasie is duidelik, naamlik twee gepolariseerde opsies waartussen gekies moet word. Daar kan geen eenheid uit hierdie besluit voortvloei nie. Die resultaat is disintegrasie, onverkwiklikheid en verdere energiedreinerende spanning in die kerklike lewe. Die vraag wat veranderingstrategies gevra moet word is wat in die besluitnemingsveld moet gebeur sodat dit nie menslike voorkeure óf wettisistiese bewaring van die status quo is wat die deurslag in besluitneming gee nie. Menslike voorkeure radikaliseer in die onverantwoordelike uitleef van vryheid.

Veranderingstrategies sou dit van kardinale belang wees om die integrerende faktor te identifiseer wat aan die hart van die Bybelse begrip van kerklike eenheid lê. Die hart van eenheid, soos dit uit die besluitnemingsproses in Handelinge 15 blyk, is die evangelie van genade in Jesus Christus. Wanneer Skrifberoep met die oog op besluitneming gebruik word, buig die Skrifverklaarder wat hom/haar deur die Gees laat lei altyd weer in selfverloëning voor Jesus Christus. Hy het die wet en die profete tot vervulling gebring en het ook mense vrygemaak om waarlik vry te wees. In Christus word mense wat in verantwoordelikheid nie van die heilige orde van God wil afwyk nie asook mense wat vrygemaakte gelowiges nie weer 
onder 'n slawejuk wil indwing nie, bymekaar gebring. In hierdie konfigurasie kan 'n disintegrerende óf-óf-besluit tot 'n integrerende énén-besluit getransformeer word

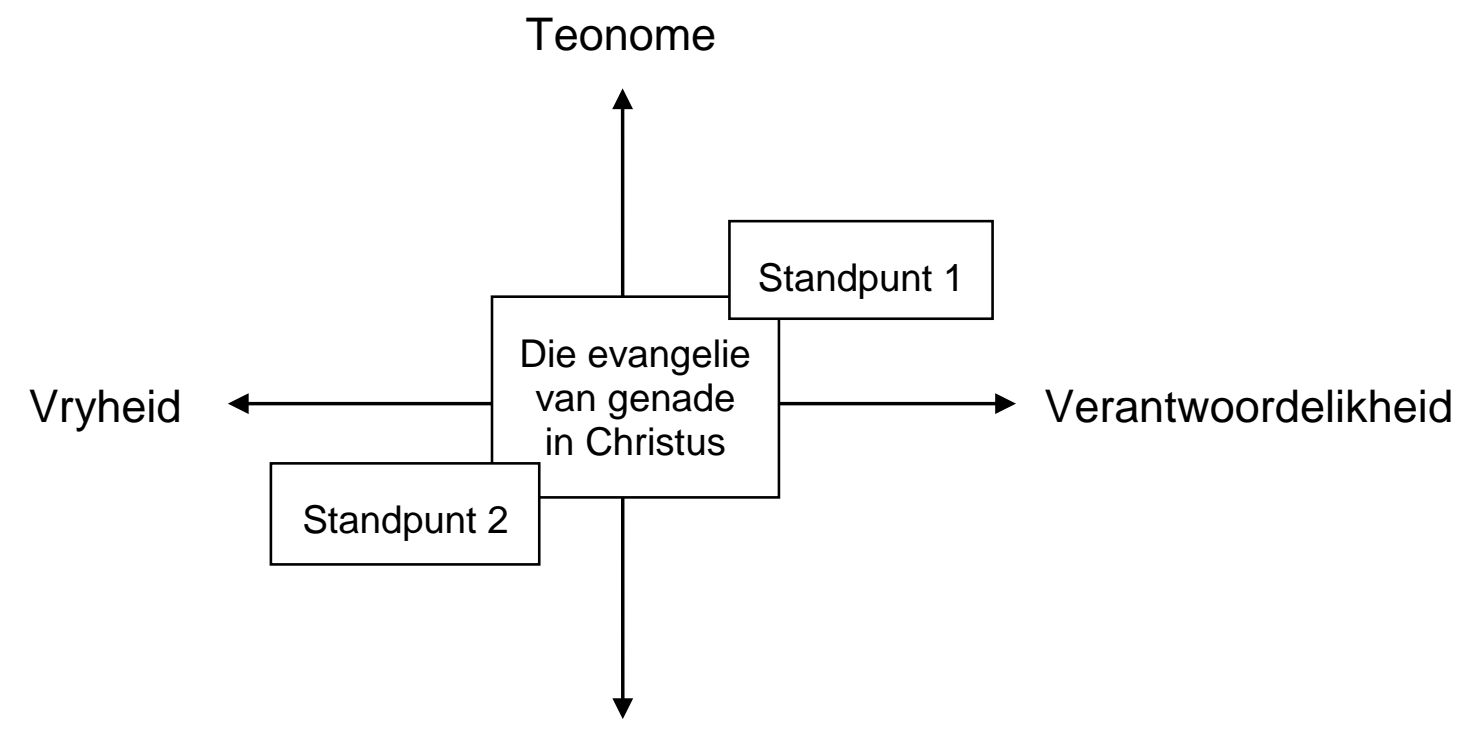

Antroponome

\section{Samevatting}

In hierdie navorsingsartikel is gepoog om veranderingstrategies te fokus op die implikasies van die vraag: In hoe 'n mate het die problematiese praksis rondom kerklike besluitneming te make met 'n oorvereenvoudigde persepsie rakende die pneumatologiese dinamika wat ter sprake kom in besluite waarvan gesê word "die Heilige Gees en ons het besluit"?

Daar is gepoog om op praktykteoretiese vlak, deur 'n visualisering van die polêre verhoudingsnetwerke in die spanningsveld van besluitneming aan besluitnemers (bepaald besluitnemers wat hulle op die Skrif beroep) 'n klankbord te gee om te kan onderskei hoe 'n besluit wat op die oog af teonoom bepaald lyk, tog deur oorheersende antroponome faktore in 'n polariserende rigting gestuur kan word. Die hart van ' $n$ veranderingstrategie waarin gepoog word om disintegrerende gesindhede en standpunte te oorkom, is na ons oordeel geleë in die versoenende krag van die evangelie van genade in Christus Jesus. Waar mense hulle deur die Gees van Christus laat lei, word besluitneming gewillig onder leiding van die Gees geplaas sonder dat die Skrif misbruik word om die eie standpunt te verabsoluteer, of om aan die ander kant die Skrif te relativeer. Waar mense hulle deur die Gees van Jesus Christus laat lei, word besluitnemers in één gemeenskap van gelowiges geïntegreer, sonder dat 
een standpunt in rigiditeit verstar en 'n ander standpunt wegdryf om in die vaarwater van ontaarding te beland.

\section{Geraadpleegde bronne}

BISSHOFF, J., MULLER, J. \& VOS, C.J.A. 2001. Kerklike leierskap in die een en twintigste eeu. Praktiese teologie in Suid-Afrika, 16(2):33-56.

CILLIERS, J. 1996. Die uitwissing van God op die kansel: ontstellende bevindinge oor Suid-Afrikaanse prediking. Wellington: Lux Verbi.BM.

CILLIERS, J. 2000. Die genade van gehoorsaamheid. Wellington: Lux Verbi.BM.

COETZEE, C.F.C. 2006. Calvyn en die eenheid van die kerk. Acta theologica, 26(1):16-35.

DE KLERK, B.J. \& JANSE VAN RENSBURG, F.J. 2005. Preekgeboorte. Potchefstroom: Potchefstroomse Teologiese Publikasies.

DE WET, F.W. 2005. Om in die gees te begin en in eie krag te eindig: die noodsaak van 'n Skrifgefundeerde prakties-teologiese pneumatologie. In die Skriflig, 39(3):505-527.

DE WET, F.W. 2007. Die funksie van pneumatologiese prediking in 'n gepolariseerde kerklike lewe. In die Skriflig, 22(1):1-22.

DE WET, F.W. \& KRUGER, F.P. 2010. 'n Prakties-teologiese perspektief op die handeling van kerklike besluitneming - verkenning en normatiewe gesigspunte. In die Skriflig, 44(1):1-25.

DEIST, F. 1982. Sê God so? Kaapstad: Tafelberg.

DEIST, F. 1986. Kan ons die Bybel dan nog glo? Pretoria: Van Schaik.

GROENEWALD, E.P. 1986. Handboek Bybelse geskiedenis. Pretoria: NG Kerkboekhandel.

GUNNINK, J. 1989. Preaching for recovery in a strife-torn church. Grand Rapids: Eerdmans.

HEFER, H. 2009. Kan 'n sinode die Here verkeerd hoor? Die Boodskapper: 225, 16 Okt.

HEITINK, G. 1993. Practical theology: history, theory, action domains - manual for practical theology. Grand Rapids: Eerdmans.

HERHOLDT, S.J. 1995. Tweede Sondag na Pase. (In Burger, C.W., Müller, B.A. \& Smit, D.J., reds. Verdere riglyne vir Paas, Hemelvaart en Pinksterprediking. Wellington: Lux Verbi.BM. p. 124-130.)

HEYNS, J.A. 1982. Teologiese etiek. Kaapstad: Nasionale Boekdrukkery.

JANSE VAN RENSBURG, F.J. \& KRUGER, S.F. 2008. Leer die Bybel self verklaar. Vereeniging: Christelike Uitgewersmaatskappy.

JOHNSTON, G. 2001. Preaching to a postmodern world: a guide to preaching for twenty first century listeners. Grand Rapids: Baker.

JOUBERT, S. 2003. God se roepstem en hoe moderne pelgrims daarop antwoord. Vereeniging: Christelike Uitgewersmaatskappy.

KRUGER, F.P. 2002. Prediking en gesindheidsverandering: 'n praktiesteologiese studie in die lig van Hebreërs. Potchefstroom: $\mathrm{PU}$ vir $\mathrm{CHO}$. (Th.D.-proefskrif.)

KRUGER, F.P. \& VENTER, C.J.H. 2002. Prediking en die gesindheid van hoorders: basisteoretiese perspektiewe vanuit Hebreërs. In die Skriflig, 36(4):573-591. 
KRUGER, F.P. \& VENTER, C.J.H. 2003. 'n Homileties-empiriese ondersoek van prediking en gesindheidsverandering. In die Skriflig, 37(3):461-483.

KÜNG, H. 1995. Christianity: it's essense and history. London: SCM.

LANDAU, R. 1981. "Komm Heiliger Geist du tröster wert." Gestaltungen des Heiligen Geistes. Evangelische Theologie, 41(3):187-211.

LARSEN, D.L. 1989. The anatomy of preaching: identifying the issues in preaching today. Grand Rapids: Kregel.

LINDNER, H. 1994. Kirche am Ort: eine Gemeindetheorie. Stuttgart: Kohlhammer.

LISSACK, M. \& ROOS, J. 2000. The next common sense: the e-manager's guide to mastering complexity. London: Brealy.

LOUW, D. 2005. Die ratwerke van die menslike siel: oor volwassenheid en lewensvaardighede. Stellenbosch: Sun Press.

MELLODY, M. \& THERON, J.P.J. 2006. Faithful servants in the house of the Lord: critical reflections on congregational management as stewardship. Praktiese teologie in Suid-Afrika, 21(3):105-121.

PIETERSE, H.J.C. 1985. Verwoording en prediking. Pretoria: NG Kerkboekhandel.

PRINS, J.M.G. 2000. Die godsdienstige houdings van kerklike betrokke tieners. Praktiese teologie in Suid-Afrika, 15(1):82-100.

SILVA, M. 1987. Has the church misread the Bible? The history of interpretation in the light of current issues. Grand Rapids: Zondervan.

SMIT, A. 1995. Nuut gedink oor leierskap in gemeentes. (In Burger, C., Hendriks, J., Van der Merwe, M. \& Smit, A., reds. Gemeente en bediening: nuut gedink oor leierskap in gemeentes - die begeleiding van 'n Christelike gemeenskap. Wellington: Lux Verbi.BM. p. 1-134.)

SMIT, C.J. 2008. Is 'n kerkorde nie kragtens sy aard strydig met die werking van die Heilige Gees nie? In die Skriflig, 42(3):393-408.

STANDER, H. 2003. Om jou Bybel beter te verstaan. Vanderbijlpark: Carpe Diem.

STOFFELS, H. 1999. Soms kom ik als een hartlike mens over: een onderzoek naar inspirerend leiderschap onder pastores van de Samen-op-Wegkerken. Nijkerk: Callenbach.

VAN DER WALT, B.J. 2009. Probleme rondom die verklaring van die Bybel in die gereformeerde teologie: 'n Christelik-filosofiese besinning. In die Skriflig, 43(1):1-27.

VAN PELT, J.W. 1999. Pastoraat in trinitarisch perspectief: de samehang tussen trinitarische en antropologische aspecten in het pastoraat. Heerenveen: Groen.

VAN ROOY, H.F. 1997. Moet jy nou praat of swyg? Gedagtes na aanleiding van Spreuke 26:4-5. Rede gelewer tydens die promosieplegtigheid van die Teologiese Skool Potchefstroom. (Ongepubliseer.)

VAN WYK, J.H. 1995. Gevare en uitdagings vir die gereformeerde teoloog vandag. Rede gelewer tydens die promosieplegtigheid van die Teologiese Skool Potchefstroom. (Ongepubliseer.)

VANHOOZER, K.J. 2005. Lost in interpretation? Truth, Scripture and hermeneutics. Journal of the Evangelical Theological Society, 41(1):89114.

VOS, C.J.A. 1996. Die volheid daarvan (1): homiletiek uit 'n hermeneutieskommunikatiewe hoek. Pretoria: RGN. 
WIARDA, T. 2003. The Jerusalem Council and the theological task. Journal of the Evangelical Theological Society, 46(2):233-248.

ZIJLSTRA, W. 1989. Op zoek naar een nieuwe horizon: handboek voor klinische pastorale vorming. Nijkerk: Callenbach.

\section{Kernbegrippe:}

kerklike besluitneming

praktykteorie (veranderingstrategie)

teonome en antroponome, verhouding tussen

\section{Key concepts:}

ecclesiastical resolutions

praxis theory (strategy for change)

teonomic and anthroponomic, relationship between 
